\title{
Minimum Quantity of Urban Refuse Compost Affecting Physical and Chemical Soil Properties
}

\author{
Paolo Bazzoffi*, Sergio Pellegrini, Andrea Rocchini \\ Istituto Sperimentale per lo Studio e la Difesa del Suolo - C.R.A. \\ Piazza D'Azeglio 30, 50121 Firenze, Italy
}

Received: 12 February 2004. Accepted: 10 November 2004

\begin{abstract}
The increasing production of urban waste requires urgent responses because of various environmental problems that arise when urban refuse is stored in landfills or incinerated. Recycling of domestic waste and composting of its organic fraction has been indicated as a possible disposal solution. A three-year experiment was conducted to quantify the minimum rate of urban refuse compost (URC) addition able to improve some physical and chemical soil properties at the lowest cost and environmental impact. URC was added to a silty clay soil and to a sandy loam soil $0 \%, 3 \%, 6 \%, 9 \%$ rate (w/w). Samplings were made 12, 24 and 36 months after URC application. To study the only effect of compost on soil due to its interaction with the soil matrix, each soil-compost mixture was divided into three boxes and kept outdoors weed free. After 12 months, 3\% URC resulted the minimum quantity able to ameliorate several soil properties. In silty clay soil this rate significantly ameliorated microaggregate stability and hydraulic conductivity, but negative effects were observed on electrical conductivity. After 24 months, $3 \%$ rate significantly increased soil organic matter content. In the sandy loam soil, after 12 months, 3\% rate of URC determined a positive effect on organic matter and cone resistance in dry soil condition. Electrical conductivity increased at $3 \%$ URC addition. The minimum URC quantity affecting hydraulic conductivity and plastic limit was $6 \%$, and $9 \%$ for the liquid limit. Under these experimental conditions, the lowest rate $(3 \%)$ of URC incorporation to soils appears to be the minimum quantity able to improve most of the soil properties influencing fertility. What the results show is that, to achieve sustainability of urban refuse compost application to agricultural soil, further research is needed to investigate soil property changes in the range between $0 \%$ and $3 \%$.
\end{abstract}

Key-words: compost, soil chemical properties, soil physical properties, sustainability, urban refuse.

\section{Introduction}

In industrialized countries problems linked to the increasing production of urban waste require urgent responses because of various environmental problems that arise when urban refuse is buried in landfills or incinerated. Finding new dump sites has become more difficult, moreover landfills are also becoming increasingly expensive, as a result of the rising costs of construction and operation (World Wildlife Fund and The Conservation Foundation, 1991). Incinerator ashes may contain hazardous materials, including heavy metals and organic compounds such as dioxin, exposing human and animal life to various risks ( $\mathrm{Hu}$ and Shy, 2001).

Recycling of domestic wastes has been indicated as a disposal solution (Poulsen et al., 1995;
Yasuda, 1996). For this reason, composting of the organic fraction of solid refuse should be encouraged (He et al., 1995; Turner et al., 1994).

The Organization for Economic Cooperation and Development (1999) reports that only $4.62 \%$ of total municipal solid waste is composted. This suggests that an increment in urban refuse compost (URC) production is possible. However, URC can be used in agriculture only if the benefits to crop production are proven and any adverse effect on soil or water is acceptable (Council of Europe, 1995; de Haan, 1989). The effects of URC on the chemical, physical and biological properties of soil have been widely reported.

A general amelioration of soil structure, porosity and hydraulic properties has almost always been demonstrated (Felton, 1995; Giu- 
squiani et al., 1995; Khaleel et al., 1981; Pagliai et al., 1981; Vigna Guidi et al., 1989).

A marked reduction of soil loss and water runoff has also been reported after mulch or manure application to soil with urban compost (Ballif and Herre, 1988; Kladivko and Nelson, 1979). Bazzoffi et al. (1998) demonstrated a 3year lasting increase in aggregate stability associated with a strong reduction in soil loss and water runoff after URC addition.

Associated with these positive effects, the application of URC may also induce soil pollution, due to residues of heavy metals and plastics. URC application can also result in nitrate losses, particularly in autumn and in the early winter. This negative effect, linked with organic matter supply to the soil, may be particularly relevant in Mediterranean areas, especially when the summer is very hot and dry. In fact, soil plowing is generally carried out in summer, with consequent acceleration of the mineralization of organic matter due to increased macroporosity and high temperatures. Under these physical conditions, occasional intense rainstorms, which often occur in summer and autumn, can produce macropore flow with high solute leaching and sub-surface transport of nitrates (Armstrong and Burt, 1993).

In order to contribute to the definition of the proper use of these organic amendments at the lowest cost and environmental impact, this study focused on the minimum quantity of URC able to induce a significant amelioration of the physical properties of soil. Information is important and studies on this subject are still minimal. This paper reports the results of an experiment carried out in Tuscany to determine the minimum quantity of URC needed to improve the physical properties of two soils of different texture and the persistence of these modifications over a three year period. The experiment was planned to isolate the effect of compost addition on soil due to microbiological and physical reaction.

In fact, the complex interaction effect of plant roots on soil aggregation has been widely proved with contrasting results, and mainly depends on soil properties, plant and tillage types (Degens et al., 1994; Materechera et al., 1994). For this reason the experiment was performed in boxes instead of being performed in the field, in order to have greater control over the ex- perimental conditions and to exclude other masking factors such as the different plant root growth, water table oscillation, crusting, soil erosion, soil compaction by tractor wheels etc.

\section{Materials and methods}

The experiment lasted three years and was carried out in Fagna, Italy, at the experimental Centre of the Institute for Soil Study and Conservation of Florence, located in Tuscany in the Mugello valley, close to the Apennine mountains. The climatic classification of the area, according to Köppen (1936), is Cfsa type (temperate with dry summer), with an average yearly rainfall of $1024 \mathrm{~mm}$. The total amounts of rainfall during the three successive years were respectively 501, 817 and $962 \mathrm{~mm}$. URC at several rates was added to two soils from the A horizon of a silty clay soil (soil 1) classified as Typic Eutrochrept and from a Typic Udifluvent soil (soil 2) with sandy loam texture (USDA, 1975; Jannone et al., 1984) at matric potential approaching -1.5 $\mathrm{MPa}$. Compost was produced through a 30-day fermentation followed by pile aerobic maturation process lasting 2 months, starting from urban refuse that was ground after removal of plastics and metals by mechanical sieving and magnetic separators. This material is dominated by non-metallic materials, especially shell and glass fragments. This composition is quite common for poor composts derived from urban refuse not subjected to separate collection. Main soils and compost characteristics are reported in Table 1.

Air dried soils were ground using a mill, and clods (aggregates) were obtained by sieving the ground material through a $4-\mathrm{cm}$ mesh. Dry compost was added to soils at $3 \%, 6 \%, 9 \%(\mathrm{w} / \mathrm{w})$, following a $2 \times 4$ factorial design with 3 replicates. A control treatment (no URC addition) was set up to assess the effects of compost application respect to non treated soils.

For each soil, aggregates were put in a cement mixer with compost, for 30 minutes, to form a dry mixture. For treatment homogeneity, the controls ( $0 \%$ treatment) were also mixed for the same time.

Each soil-compost mixture was divided into 3 wooden boxes (100 cm long, $50 \mathrm{~cm}$ wide and $20 \mathrm{~cm}$ deep). Each box was filled with $100 \mathrm{~kg}$ 
Table 1. Physical and chemical characteristics of soils and urban refuse compost (standard errors in brackets).

\begin{tabular}{|c|c|c|c|c|}
\hline \multicolumn{3}{|l|}{ Main soils characteristics } & \multicolumn{2}{|l|}{ URC composition (on dry weight) } \\
\hline & Soil 1 & Soil 2 & $\operatorname{Ash}\left(550^{\circ} \mathrm{C}\right)(\%)$ & 64.0 \\
\hline Gravel (> $2000 \mu \mathrm{m})(\%)$ & 0.0 & 0.0 & Glass and shell residues $>2 \mathrm{~mm}(\%)$ & 20.8 \\
\hline Sand $(50-2000 \mu \mathrm{m})(\%)$ & $11.8(0.37)$ & $57.2(0.58)$ & Glass and shell residues $<2 \mathrm{~mm}(\%)$ & 37.1 \\
\hline Silt $(2-50 \mu \mathrm{m})(\%)$ & $42.2(1.20)$ & $25.3(0.30)$ & Sand $2-1 \mathrm{~mm}(\%)$ & 12.17 \\
\hline Clay $(<2 \mu \mathrm{m})(\%)$ & $46.0(0.40)$ & $17.5(0.34)$ & Sand 1-0.5 mm (\%) & 9.20 \\
\hline Texture & Silty clay & Sandy loam & Organic matter (ignition) (\%) & 36.02 \\
\hline CEC (me/100 g) & $33.7(0.18)$ & $13.1(0.17)$ & Plastics $(\%)$ & 0.1 \\
\hline $\mathrm{pH}(1: 2.5) \mathrm{H}_{2} \mathrm{O}$ & $7.76(0.01)$ & $8.04(0.003)$ & Ferrous metal (\%) & 0.1 \\
\hline Organic matter (\%) & $1.32(0.14)$ & $1.5(0.12)$ & $\mathrm{pH}(1: 2.5) \mathrm{H}_{2} \mathrm{O}$ & 7.5 \\
\hline $\mathrm{CaCO}_{3}(\%)$ & $10.5(0.97)$ & $6.0(0.48)$ & Electrical conductivity $\left(\mathrm{dS} \mathrm{m} \mathrm{m}^{-1}\right)$ & 4.7 \\
\hline Total N (Kjieldahl) (\%o) & $1.23(0.06)$ & $1.11(0.05)$ & $\mathrm{C} / \mathrm{N}$ & 21 \\
\hline Total P (\%o) & $0.4(0.03)$ & $0.6(0.04)$ & Total N (Kjieldahl) (\%о) & 0.98 \\
\hline Total K (\%o) & $1.2(0.06)$ & $1.0(0.06)$ & Total P (\%o) & 0.2 \\
\hline & & & Total K (\%o) & 0.6 \\
\hline & & & $\mathrm{Cu}\left(\mathrm{mg} \mathrm{kg}^{-1}\right)$ & 248 \\
\hline & & & $\mathrm{Zn}\left(\mathrm{mg} \mathrm{kg}^{-1}\right)$ & 540 \\
\hline & & & $\mathrm{Pb}\left(\mathrm{mg} \mathrm{kg}^{-1}\right)$ & 626 \\
\hline & & & $\mathrm{Ni}\left(\mathrm{mg} \mathrm{kg}^{-1}\right)$ & 28 \\
\hline & & & $\mathrm{Cr}\left(\mathrm{mg} \mathrm{kg}^{-1}\right)$ & 36 \\
\hline & & & $\mathrm{Cd}\left(\mathrm{mg} \mathrm{kg}^{-1}\right)$ & 9.1 \\
\hline & & & $\mathrm{Hg}\left(\mathrm{mg} \mathrm{kg}^{-1}\right)$ & 1.6 \\
\hline & & & As $\left(\mathrm{mg} \mathrm{kg}^{-1}\right)$ & 1.2 \\
\hline
\end{tabular}

of mixture. Before filling, a 3-cm layer of draining rubble $(1-1.5 \mathrm{~cm}$ size) was put on the bottom of each box. Subsequently, the 24 boxes were placed in cement containers to soak by capillary rise, for 24 hours, then placed to dry outdoors. Water level, inside the soaking tank, was set $1 \mathrm{~cm}$ above the strata of rubble. Wetting-drying cycles were repeated three times, at intervals of 7 days during summer, to accelerate the aggregation process of soil particles and compost reaction. The boxes were then placed outdoors on wooden pallets, set in a row, and covered with a plastic net of $<1 \mathrm{~mm}$-opening size at a distance of $5 \mathrm{~cm}$ from soil surface, to prevent crust formation by raindrop impact.

Soil surface was permanently kept free of weeds with herbicide (Glyphosate).

Measurements were taken after 12, 24 and 36 months from the beginning of the experiment by collecting one sample per box.

The following variables were determined: a) particle size distribution, b) macroaggregate stability, c) microaggregate stability, d) Atterberg limits, e) bulk density, f) penetrometer resistance (cone resistance) at two water contents, corresponding respectively at $-1.5 \mathrm{MPa}$ and -0.033 MPa suction (12 months after URC application only), g) available water capacity (AWC), h) saturated hydraulic conductivity, i) organic matter $(\mathrm{OM})$ content, j) $\mathrm{pH}\left(1: 2.5 \mathrm{H}_{2} \mathrm{O}\right)$, k) electrical conductivity.

The particle size distribution was determined using the hydrometer method and sieving (Gee and Bauder, 1986). To evaluate macroaggregate stability, the mean weight diameter (MWD) of water stable aggregates was determined by the procedure described by Kemper and Chepil (1965). Undisturbed soil samples of the surface $(0-20 \mathrm{~cm})$ were taken in triplicate. After drying at room temperature, the samples were broken down into smaller mechanical aggregates using a rubber hammer. The sample, passed through a 4-mm mesh and retained at the 2-mm mesh, was used for analyses. The MWD was determined on $25 \mathrm{~g}$ of dry aggregates of less than $-1.5 \mathrm{MPa}$ water potential. The samples were directly soaked for 10 minutes on the top of a nest of sieves of 2, 1, 0.5 and $0.25 \mathrm{~mm}$ immersed in water. The nest of sieves and its content was then vertically shaken in water by an electronic-controlled machine with a stroke of $4 \mathrm{~cm}$ per 10 minutes, at a rate of 30 complete oscillations per minute. The mass of oven-dried particles $\left(105^{\circ} \mathrm{C}\right.$ for 24 hours) that resisted breakdown was determined in each sieve. The mass of the fraction passed through the $0.25-\mathrm{mm}$ sieve was obtained by difference.

The respective dry masses were used to com- 
pute the MWD according to Van Bavel (1949), as follows:

$$
\mathrm{MWD}=\sum_{\mathrm{i}=1}^{\mathrm{n}} \mathrm{W}(i) \mathrm{X}_{i}
$$

where:

MWD is the mean weight diameter (mm); $\mathrm{X} i$ is the arithmetic mean diameter of the $i$ and $i-1$ sieve openings $(\mathrm{mm}) ; \mathrm{W}(i)$ is the proportion of the total sample mass (corrected for sand and gravel) occurring in the fraction (dimensionless); $\mathrm{n}$ is the number of size fractions (in this case 5).

Microaggregate stability, in the domain of the aggregated silt+clay particle's size, was measured with the Iif index (Chisci et al., 1989) as follows:

$$
\text { Iif }=100-\left(\begin{array}{l}
\mathrm{SCW} \% \\
\mathrm{SCC} \%
\end{array} \cdot 100\right)
$$

where:

SCW $\%=\%$ of silt + clay determined in the water-dispersed sample; SCC $\%=\%$ of silt + clay determined in the calgon-dispersed sample.

The index of microaggregate stability was chosen to detect the effect of OM incorporation on small aggregates. In fact, humic substances linked to polyvalent cations may have increased cohesion between clay particles (Krishna Murthi and Huang, 1987; Monreal et al., 1995), with a consequent increase of microaggregate stability.

Macroaggregate and microaggregate stability increase according to the increase of MWD and Iif indexes respectively.

Atterberg limits (liquid and plastic limits) were chosen to detect the magnitude of the range of the moisture contents over which the soil is in a plastic condition. Plastic limit is the lowest moisture content at which the soil can be rolled into threads $3 \mathrm{~mm}$ in diameter without the threads crumbling. The increase of the plastic limit is often considered positive with respect to the capability of soil to be tilled (soil workability) (Hillel, 1980; Dexter, 1988). Liquid limit indicates the minimum water content at which the soil changes from a viscous liquid to a plastic solid. An increase in the liquid limit of a soil is considered positive, especially in clay soils, due to the decrease of risk of landslides. Both limits are strongly dependent on the colloidal fraction content of soil (Yong and Warkentin, 1966).

Atterberg limits for different soils and treatments were determined according to Bowles
(1986). Bulk density was performed using the core method (Blake and Hartge, 1986) at 0-5 cm depth. Sampling was done in dry conditions approaching $-1.5 \mathrm{MPa}$ water content.

In-field cone resistance was measured by a self-recording electronic penetrometer (Eijkelkamp Agrisearch Equipment BV - The Netherlands) following ASAE standard procedures (ASAE, 1982). This analysis was chosen in consideration of the correlation, demonstrated by different authors, of cone resistance with some quantitative and qualitative parameters, such as wheel compaction, crustability, compressibility, workability, erodibility, bulk density, root growth, seedling emergence, plant yield etc. (Bradford, 1986; Dexter, 1987; Raper et al., 1994; Taylor, 1971; Whalley et al., 1995). Penetration tests were performed at field capacity and wilting point water content (-0.033 and -1.5 MPa respectively - Bradford, 1986).

Available water capacity (AWC) was determined as the difference between water content $\%(\mathrm{w} / \mathrm{w})$ at field capacity (-0.033 MPa suction) and wilting point (-1.5 MPa suction). The two water contents were determined using pressure plate apparatus (Klute, 1986). Hydraulic conductivity of saturated soil was determined in the laboratory by the constant head method according to Klute and Dirksen (1986).

Organic matter content was determined following the wet combustion technique (Walkley and Black, 1934). Electrical conductivity was measured by the 1:5 (v/v) soil:water extract method (Rhoades, 1996).

Different statistical analyses were carried out using ANOVA. By considering that four rates of URC were used in the experiment, equally spaced from each other, the main effects on soil properties have been partitioned into three orthogonal contrasts (linear, quadratic and cubic). Through ANOVA, the LSD mean separation was also determined. Furthermore, the month $\mathrm{x}$ URC interaction was determined when soil properties were measured at different times from URC application.

When a linear, quadratic or cubic trend was found, the corresponding equation coefficients were determined by running regressions on the treatment levels (X) for the linear case, on the treatment levels $(\mathrm{X})$ and $\mathrm{X}^{2}$ for the quadratic fit and on $\mathrm{X}, \mathrm{X}^{2}$ and $\mathrm{X}^{3}$, for the cubic fit (Nemec, 1991). 


\section{Results and discussion}

\subsection{Size distribution of primary particles}

Particle size distribution of $<2$-mm particles of the silty clay soil showed an increase of sand and a decrease in silt and clay fractions with increasing rates of URC addition. The difference between control and treatment samples reached the statistical significance only for the sand fraction at $6 \%$ and $9 \%$ rates of URC addition (Table 2).

Similarly, the sand fraction increased in the sandy loam soil but statistical significance was reached only for the highest rate of compost addition. Both soils showed a significant linear increase of total sand content and in the sand fraction in the classes 2-1 mm and 1-0.5 mm (Table 2).

In the silty clay soil a significant linear and quadratic effect was detected (Table 6). This effect may have been produced as a consequence of the high content of these particle size fractions in URC (Table 1). The possible effect on soil texture (USDA, 1975) of repeated application over $9 \%$ of cumulated URC addition can be extrapolated from linear trends of variation of sand, silt and clay (Tables 6 and 7), obtained by orthogonal contrast analysis in the range 0 $9 \%$ of URC. Silty clay soil tends to change towards a loam texture at URC rates $>50 \%$. On the contrary, the same amount of URC seems not effective in changing the textural class of the sandy loam soil.

From these estimates it can be argued that the original silty clay matrix is more prone to textural change than the sandy loam one.

\subsection{Structural stability}

In the silty clay soil, the MWD of water stable macroaggregates was significantly increased 12 and 24 months after URC application with respect to non treated soil. This effect disappeared after 36 months (Table 3 ).
In the sandy loam soil, after 12 months, the differences of MWD with respect to non treated soil were not statistically significant (Table 4). After 24 months URC increased the MWD of water stable aggregates. Statistical significance for differences increased in accordance with the increase of compost addition and a clear mean separation was observed comparing $0 \%$ and $9 \%$ rates. After 36 months, the effect of compost on MWD became more evident and a significant mean separation was observed starting from $3 \%$ rate of URC addition.

After 12 and 24 months in the silty clay soil and after 24 and 36 months in sandy loam soil, the structural stability of macroaggregates showed a significant linear positive trend with the increase of URC addition in both soils. This finding demonstrated the effectiveness of URC addition on this important parameter of soil fertility, already starting from 3\% rate.

After 24 and 36 months following URC addition, microaggregate stability (Iif index) of both soils was generally higher than after 12 months (Tables 3 and 4), This effect was detected also in the control soil ( $0 \%$ URC). In fact, microaggregate stability significantly increased after 24 months where no compost was applied ( $0 \%$ rate). This effect was likely to have been caused by the natural capacity of soil primary particles to aggregate under the effect of different binding agents, especially aromatic humic materials associated to amorphous $\mathrm{Fe}$ and Al compounds, as well as to polyvalent metal cations (Tisdall and Oades, 1982). Twelve months of reaction of compost with soil matrix of both soils did not appear sufficient to determine significant effects on the Iif index. This result can be explained by considering that persistent binding agents, which are responsible for the stability of microaggregates, act slower than

Table 2. Effect of different rates of URC addition on particle size distribution of the two soils. (LSD test at $\mathrm{P} \leq 0.05$ ).

\begin{tabular}{lcccccccccc}
\hline URC \% & \multicolumn{10}{l}{ Silty claySandy loam } \\
\hline & $\begin{array}{c}\text { total } \\
\text { sand } \\
(\%)\end{array}$ & $\begin{array}{c}2-1 \mathrm{~mm} \\
\text { sand } \\
(\%)\end{array}$ & $\begin{array}{c}1-0.5 \\
\text { mm sand } \\
(\%)\end{array}$ & $\begin{array}{c}\text { Silt } \\
(\%)\end{array}$ & $\begin{array}{c}\text { Clay } \\
(\%)\end{array}$ & $\begin{array}{c}\text { total } \\
\text { sand } \\
(\%)\end{array}$ & $\begin{array}{c}2-1 \mathrm{~mm} \\
\text { sand } \\
(\%)\end{array}$ & $\begin{array}{c}1-0.5 \\
\text { mm sand } \\
(\%)\end{array}$ & $\begin{array}{c}\text { Silt } \\
(\%)\end{array}$ & $\begin{array}{c}\text { Clay } \\
(\%)\end{array}$ \\
\hline 0 & 11.8 & 0.3 & 0.3 & 42.2 & 46.0 & 57.2 & 0.4 & 2.7 & 25.3 & 17.5 \\
3 & 12.4 & 0.9 & 1.2 & 42.1 & 45.5 & 57.9 & 1.1 & 3.6 & 25.0 & 17.1 \\
6 & 14.1 & 1.5 & 1.7 & 41.7 & 44.2 & 58.5 & 1.8 & 4.1 & 24.7 & 16.8 \\
9 & 15.4 & 2.3 & 2.1 & 40.8 & 43.8 & 59.4 & 2.3 & 5.8 & 24.1 & 16.5 \\
LSD $_{\text {URC }}$ & 1.6 & 0.3 & 0.3 & 3.7 & 1.5 & 1.5 & 0.2 & 1.9 & 1.1 & 1.4 \\
\hline
\end{tabular}


Table 3. Effect of different rates of URC addition on silty clay soil properties at different times. (LSD test at $\mathrm{P} \leq 0.05$ ).

\begin{tabular}{|c|c|c|c|c|c|}
\hline Variables & $\%$ URC & 12 months & 24 months & 36 months & $\mathrm{LSD}_{\text {months }}$ \\
\hline \multirow[t]{5}{*}{ MWD (mm) } & 0 & 1.09 & 0.97 & 1.48 & 0.47 \\
\hline & 3 & 1.10 & 1.32 & 1.45 & 0.38 \\
\hline & 6 & 1.48 & 1.55 & 1.31 & 0.53 \\
\hline & 9 & 1.83 & 1.68 & 1.48 & 0.55 \\
\hline & $\mathrm{LSD}_{\mathrm{URC}}$ & 0.59 & 0.39 & 0.36 & \\
\hline \multirow[t]{5}{*}{ Iif $(\%)$} & 0 & 56.72 & 69.61 & 63.75 & 6.65 \\
\hline & 3 & 51.77 & 66.78 & 67.38 & 4.72 \\
\hline & 6 & 52.82 & 68.92 & 66.81 & 3.26 \\
\hline & 9 & 52.43 & 71.64 & 68.54 & 5.97 \\
\hline & $\mathrm{LSD}_{\mathrm{URC}}$ & 3.81 & 6.65 & 4.04 & \\
\hline \multirow[t]{5}{*}{ Bulk density $\left(\mathrm{g} \mathrm{cm}^{-3}\right)$} & 0 & 1.44 & 1.41 & 1.42 & 0.07 \\
\hline & 3 & 1.47 & 1.42 & 1.46 & 0.07 \\
\hline & 6 & 1.50 & 1.45 & 1.47 & 0.07 \\
\hline & 9 & 1.57 & 1.54 & 1.56 & 0.09 \\
\hline & $\mathrm{LSD}_{\mathrm{URC}}$ & 0.06 & 0.04 & 0.10 & \\
\hline \multirow[t]{5}{*}{ Organic matter $(\%)$} & 0 & 1.30 & 1.34 & 1.54 & 0.25 \\
\hline & 3 & 1.61 & 1.74 & 1.85 & 0.13 \\
\hline & 6 & 2.41 & 2.09 & 2.12 & 0.71 \\
\hline & 9 & 3.17 & 2.62 & 2.28 & 1.01 \\
\hline & $\mathrm{LSD}_{\mathrm{URC}}$ & 1.00 & 0.18 & 0.20 & \\
\hline \multirow[t]{5}{*}{$\mathrm{pH}$} & 0 & 7.96 & 7.97 & 7.99 & 0.11 \\
\hline & 3 & 7.74 & 7.86 & 7.87 & 0.15 \\
\hline & 6 & 7.61 & 7.83 & 7.95 & 0.12 \\
\hline & 9 & 7.62 & 7.82 & 8.09 & 0.11 \\
\hline & $\mathrm{LSD}_{\mathrm{URC}}$ & 0.36 & 0.17 & 0.24 & \\
\hline \multirow[t]{5}{*}{ Electrical cond. $\left(\mathrm{dS} \mathrm{m}^{-1}\right)$} & 0 & 0.20 & 0.20 & 0.20 & 0.08 \\
\hline & 3 & 0.42 & 0.35 & 0.22 & 0.07 \\
\hline & 6 & 0.51 & 0.40 & 0.23 & 0.07 \\
\hline & 9 & 0.69 & 0.51 & 0.22 & 0.06 \\
\hline & $\mathrm{LSD}_{\mathrm{URC}}$ & 0.07 & 0.07 & 0.06 & \\
\hline \multirow[t]{5}{*}{ AWC (\%) } & 0 & 14.11 & 13.88 & 12.19 & 1.69 \\
\hline & 3 & 15.09 & 15.18 & 13.12 & 1.42 \\
\hline & 6 & 13.61 & 14.89 & 12.44 & 0.72 \\
\hline & 9 & 13.46 & 14.92 & 12.53 & 2.23 \\
\hline & $\mathrm{LSD}_{\mathrm{URC}}$ & 2.00 & 1.23 & 1.18 & \\
\hline
\end{tabular}

transient agents in the process of aggregation (Edwards and Bremner, 1967).

In the sandy loam soil, after 24 months (Table 4), microaggregate stability decreased with increasing rates of URC application, being significant at 6 and $9 \%$ rate. This effect persisted, although attenuated, after 36 months, with a significant mean separation at $9 \%$ rate.

In contrast to the sandy loam soil, microaggregate stability of the silty clay soil reacted positively to URC addition, although this effect was small, as demonstrated by the values on Table 3. In fact, after 24 months, differences did not reach the significant level. Only after 36 months a significant difference was observed with rates of URC addition $\geq 3 \%$.

The negative effect of URC on microaggregation of sandy loam soil can be explained by considering that soils need at least $15-20 \%$ of clay to form aggregates and to begin to express an aggregate structure in which clay particles can bind the coarser soil constituents and organic matter (Hayes, 1991; Horn et al., 1994). The amount of clay in this soil, being $17.5 \%$, may not have been sufficient to react with all the organic matter provided by URC.

The decrease of microaggregate stability after 24 months showed a significant linear negative trend with the increase of URC addition in both soils (Table 6 and 7). In the sandy soil this trend persisted after 36 months.

From the positive effect on macroaggregation and negative effect on microaggregation up to 24 months, it can be argued that, for both soils, the predominant effect on aggregate stability may be caused by the binding action of temporary cementing agents (Tisdall and Oades, 1982). This argument is strongly supported 
Table 4. Effect of different rates of URC addition on sandy loam soil properties at different times (LSD test at P $\leq 0.05$ ).

\begin{tabular}{|c|c|c|c|c|c|}
\hline Variables & $\%$ URC & 12 months & 24 months & 36 months & $\mathrm{LSD}_{\text {months }}$ \\
\hline \multirow[t]{5}{*}{ MWD (mm) } & 0 & 0.75 & 0.44 & 0.51 & 0.50 \\
\hline & 3 & 1.15 & 0.61 & 1.01 & 0.87 \\
\hline & 6 & 1.31 & 0.75 & 0.94 & 0.65 \\
\hline & 9 & 0.90 & 0.92 & 1.01 & 0.60 \\
\hline & $\mathrm{LSD}_{\mathrm{URC}}$ & 0.93 & 0.41 & 0.40 & \\
\hline \multirow[t]{5}{*}{ Iif $(\%)$} & 0 & 17.96 & 26.45 & 29.48 & 3.77 \\
\hline & 3 & 15.83 & 23.42 & 27.01 & 3.49 \\
\hline & 6 & 17.49 & 22.26 & 24.74 & 4.05 \\
\hline & 9 & 17.03 & 21.71 & 21.80 & 6.33 \\
\hline & $\mathrm{LSD}_{\mathrm{URC}}$ & 3.76 & 3.57 & 5.32 & \\
\hline \multirow[t]{5}{*}{ Bulk density $\left(\mathrm{g} \mathrm{cm}^{-3}\right)$} & 0 & 1.54 & 1.52 & 1.47 & 0.05 \\
\hline & 3 & 1.50 & 1.50 & 1.46 & 0.04 \\
\hline & 6 & 1.42 & 1.47 & 1.45 & 0.06 \\
\hline & 9 & 1.35 & 1.39 & 1.38 & 0.05 \\
\hline & $\mathrm{LSD}_{\mathrm{URC}}$ & 0.07 & 0.10 & 0.05 & \\
\hline \multirow[t]{5}{*}{ Organic matter (\%) } & 0 & 1.54 & 1.46 & 1.61 & 0.21 \\
\hline & 3 & 1.83 & 1.90 & 1.86 & 0.17 \\
\hline & 6 & 2.17 & 2.19 & 2.34 & 0.36 \\
\hline & 9 & 3.19 & 3.02 & 2.47 & 0.51 \\
\hline & $\mathrm{LSD}_{\mathrm{URC}}$ & 0.26 & 0.12 & 0.48 & \\
\hline \multirow[t]{5}{*}{$\mathrm{pH}$} & 0 & 8.04 & 8.03 & 8.04 & 0.10 \\
\hline & 3 & 7.92 & 7.95 & 7.99 & 0.19 \\
\hline & 6 & 7.81 & 7.83 & 8.03 & 0.17 \\
\hline & 9 & 7.76 & 7.75 & 8.01 & 0.21 \\
\hline & $\mathrm{LSD}_{\mathrm{URC}}$ & 0.18 & 0.08 & 0.11 & \\
\hline \multirow[t]{5}{*}{ Electrical cond. $\left(\mathrm{dS} \mathrm{m} \mathrm{m}^{-1}\right)$} & 0 & 0.27 & 0.27 & 0.27 & 0.06 \\
\hline & 3 & 0.39 & 0.26 & 0.26 & 0.05 \\
\hline & 6 & 0.58 & 0.33 & 0.26 & 0.10 \\
\hline & 9 & 0.61 & 0.41 & 0.27 & 0.06 \\
\hline & $\mathrm{LSD}_{\mathrm{URC}}$ & 0.05 & 0.09 & 0.06 & \\
\hline \multirow[t]{5}{*}{ AWC (\%) } & 0 & 13.69 & 16.42 & 10.92 & 0.97 \\
\hline & 3 & 12.86 & 14.47 & 10.71 & 1.36 \\
\hline & 6 & 13.64 & 14.68 & 11.22 & 1.31 \\
\hline & 9 & 13.66 & 14.13 & 11.07 & 1.49 \\
\hline & $\mathrm{LSD}_{\text {URC }}$ & 1.60 & 1.21 & 0.68 & \\
\hline
\end{tabular}

by the direct observation, during the first year, of a conspicuous fungal mycelium and sporocarps blooming on the surface of URC-added soil boxes only. Although fungal presence was not quantified, its positive effect as binding agent of aggregates (Jackson, 1975; Marshall, 1976) during the three years seems plausible.

\subsection{Bulk density}

Bulk density of the silty clay soil increased with increasing rates of URC supplied to the soil. The statistical significance for the difference, with respect to the untreated soil, was achieved only at $9 \%$ rate (Table 3 ). This effect, detected after 12 months, persisted after 24 and 36 months. The increase in bulk density in the silty clay soil in response to compost addition was likely related to the large amount of material with high specific gravity (shell and glass frag- ments) contained in the compost. This effect was probably not sufficiently counteracted by the supply of organic matter, having lower bulk density, to soil. A significant linear positive trend was detected after 12, 24 and 36 months from URC application (Table 6). After 24 months also the quadratic trend resulted significant, showing a steep increase of bulk density above $3 \%$ rate. The interaction URC $\mathrm{x}$ months resulted significant (Table 8). Thus, the effect of different rates of URC on bulk density resulted partly time-dependent, probably due to the different microbiological activity in soil when different quantities of organic matter are present (Wander et al., 1994). The effect of URC on bulk density of the sandy loam soil was the opposite of the effect observed in the silty clay soil (Table 4). In fact, after 12 and 24 months 
Table 5. Effect of different rates of URC addition on soil properties 12 months after addition (LSD test at $\mathrm{P} \leq 0.05)$.

\begin{tabular}{|c|c|c|c|}
\hline Variables & $\%$ URC & Silty clay soil & Sandy loam soil \\
\hline \multirow[t]{5}{*}{ Liquid limit moisture $(\% \mathrm{w} / \mathrm{w})$} & 0 & 58.41 & 34.60 \\
\hline & 3 & 63.44 & 35.49 \\
\hline & 6 & 62.27 & 36.40 \\
\hline & 9 & 63.09 & 39.97 \\
\hline & $\mathrm{LSD}_{\mathrm{URC}}$ & 6.82 & 1.94 \\
\hline \multirow[t]{5}{*}{ Plastic limit moisture $(\% \mathrm{w} / \mathrm{w})$} & 0 & 22.17 & 19.28 \\
\hline & 3 & 24.07 & 19.11 \\
\hline & 6 & 24.17 & 21.12 \\
\hline & 9 & 23.51 & 21.36 \\
\hline & $\mathrm{LSD}_{\mathrm{URC}}$ & 2.30 & 1.51 \\
\hline \multirow[t]{5}{*}{ Cone resistance $(\mathrm{kPa})$ at $-0.033 \mathrm{MPa}$ water content } & 0 & 241 & 397 \\
\hline & 3 & 240 & 309 \\
\hline & 6 & 349 & 348 \\
\hline & 9 & 418 & 361 \\
\hline & $\mathrm{LSD}_{\mathrm{URC}}$ & 68 & 428 \\
\hline \multirow[t]{5}{*}{ Cone resistance $(\mathrm{kPa})$ at $-1.5 \mathrm{MPa}$ water content } & 0 & 1765 & 3244 \\
\hline & 3 & 1929 & 2605 \\
\hline & 6 & 2422 & 2953 \\
\hline & 9 & 2530 & 3040 \\
\hline & $\mathrm{LSD}_{\mathrm{URC}}$ & 404 & 471 \\
\hline \multirow{6}{*}{$\begin{array}{l}\text { Saturated } \\
\text { hydraulic conductivity } \\
\left(\mathrm{cm} \mathrm{h}^{-1}\right)\end{array}$} & & & \\
\hline & 0 & 0.27 & 0.85 \\
\hline & 3 & 0.45 & 1.02 \\
\hline & 6 & 0.46 & 2.28 \\
\hline & 9 & 0.65 & 7.26 \\
\hline & $\mathrm{LSD}_{\mathrm{URC}}$ & 0.14 & 0.58 \\
\hline
\end{tabular}

bulk density decreased with the increase in compost addition, becoming significantly lower than untreated soil at $6 \%$ and $9 \%$ rate. At 36 months after compost application the effect persisted, although the statistical significance for differences was achieved only at $9 \%$ rate.

ANOVA analysis demonstrated a significant linear negative trend on bulk density for the sandy loam soil at 24 and 36 months (Table 7). On the contrary, the trend was not significant after 12 months from URC application. With respect to silty clay soil, the opposite effect of compost on bulk density of sandy loam soil may be explained by the same dilution effect and by the effect of organic matter supplied to soil. In fact, the incorporation into soil of a biomass with a lower content of sand fraction $(43.0 \%)$ than the sandy loam soil $(57.2 \%)$ and the supply of organic matter would likely have determined the decrease of bulk density in the sandy loam soil.

\subsection{Organic matter}

The organic matter content of both soils increased with increasing rates of compost addition. In the silty clay soil the effect was almost the same as that observed for the sandy loam soil (Table 3). In the silty clay soil, after 12 months the significance for the effect of URC on organic matter was achieved at $9 \%$ rate. Furthermore, $3 \%$ and $6 \%$ resulted intergrades between $0 \%$ and $9 \%$. At 24 months from URC application, the differences between means were more significant and the effect persisted at 36 months. In the sandy loam soil, differences were very significant at 12 and 24 months after URC application (Table 4). In this soil, after 36 months the effect of $3 \%$ rate did not differ significantly from $0 \%$, while a significant difference was still present at $6 \%$ and $9 \%$ rates of URC addition. These findings suggest that the minimum rate of $6 \%$ must be applied to achieve a lasting effect on soil organic matter.

Both soils showed a significant linear trend in organic matter after 12, 24 and 36 months (Table 6 and 7). For the sandy loam soil the quadratic trend was significant after 12 and 24 months, showing a rapid increase of organic matter over $3 \%$ of URC addition. Furthermore after 36 month the cubic trend also resulted significant. However the cubic trend did not add 
Table 6. Orthogonal contrasts from ANOVA, for the silty clay soil. Only significant contrasts $(\mathrm{P} \leq 0.05)$ are reported. d.f. for contrasts $=1$; d.f. for error $=8$

Linear model: $\mathrm{Y}=\mathrm{A}+\mathrm{BX}$, quadratic: $\mathrm{Y}=\mathrm{A}+\mathrm{BX}+\mathrm{CX}^{2}$; cubic: $\mathrm{Y}=\mathrm{A}+\mathrm{BX}+\mathrm{CX}^{2}+\mathrm{DX}^{3}$, where $\mathrm{X}=\mathrm{URC} \%$

\begin{tabular}{|c|c|c|c|c|c|c|c|c|c|c|c|c|c|c|c|c|}
\hline \multirow[t]{2}{*}{ Variables } & \multicolumn{3}{|c|}{ Linear } & \multicolumn{5}{|c|}{ Quadratic } & \multicolumn{3}{|c|}{ Cubic } & \multicolumn{3}{|c|}{ error } & \multirow[b]{2}{*}{$\mathrm{D}$} & \multirow[b]{2}{*}{ S.S. } \\
\hline & S.S. & $\mathrm{F}$ & A & $\mathrm{B}$ & S.S. & $\mathrm{F}$ & A & $\mathrm{B}$ & $\mathrm{C}$ & S.S. & $\mathrm{F}$ & A & B & $\mathrm{C}$ & & \\
\hline Total sand & 22.566 & 30.4 & 11.58 & 0.41 & & & & & & & & & & & 5.9368 & \\
\hline 2-1 mm sand & 6.617 & 204.9 & 0.256 & 0.221 & & & & & & & & & & & 0.2583 & \\
\hline $1-0.5 \mathrm{~mm}$ sand & 4.959 & 285.9 & 0.446 & 0.192 & 0.187 & 10.8 & 0.321 & 0.317 & -0.014 & & & & & & 0.1387 & \\
\hline Total clay & 9.025 & 15.1 & 46.010 & -0.259 & & & & & & & & & & & 4.7957 & \\
\hline $\mathrm{MWD}_{12 \mathrm{months}}$ & 1.008 & 10.3 & 0.991 & 0.086 & & & & & & & & & & & & 0.7847 \\
\hline $\mathrm{MWD}_{24 \text { months }}$ & 0.828 & 19.3 & 1.025 & 0.078 & & & & & & & & & & & & 0.3439 \\
\hline $\mathrm{IIF}_{36 \text { months }}$ & 28.567 & 6.2 & 64.548 & 0.460 & & & & & & & & & & & & 36.874 \\
\hline Bulk density $_{12 \text { months }}$ & 0.026 & 23.6 & 1.434 & 0.014 & & & & & & & & & & & & 0.0091 \\
\hline Bulk density $_{24 \text { months }}$ & 0.026 & 49.1 & 1.397 & 0.014 & 0.005 & 8.9 & 1.417 & -0.006 & 0.002 & & & & & & & 0.0043 \\
\hline Bulk density ${ }_{36 \text { months }}$ & 0.027 & 9.8 & 1.416 & 0.014 & & & & & & & & & & & & 0.0022 \\
\hline Org. matter ${ }_{12 \text { months }}$ & 6.12 & 21.8 & 1.165 & 0.213 & & & & & & & & & & & & 2.2458 \\
\hline Org. matter ${ }_{24 \text { months }}$ & 2.633 & 274.3 & 1.319 & 0.140 & & & & & & & & & & & & 0.0768 \\
\hline Org. matter ${ }_{36 \text { months }}$ & 0.940 & 82.3 & 1.574 & 0.083 & & & & & & & & & & & & 0.0913 \\
\hline $\mathrm{pH}_{12 \text { months }}$ & 0.196 & 43.1 & 7.907 & -0.038 & 0.041 & 9.1 & 7.965 & -0.097 & 0.006 & & & & & & & 0.0363 \\
\hline $\mathrm{pH}_{24 \text { months }}$ & 0.034 & 21.9 & 7.945 & -0.016 & 0.007 & 4.6 & 7.970 & -0.040 & 0.003 & & & & & & & 0.0125 \\
\hline Electr. cond. ${ }_{12 \text { months }}$ & 0.365 & 240.9 & 0.225 & 0.052 & & & & & & & & & & & & 0.0121 \\
\hline Electr. cond. ${ }_{24 \text { months }}$ & 0.145 & 123.1 & 0.220 & 0.033 & & & & & & & & & & & & 0.0093 \\
\hline Cone resist. $-1.5 \mathrm{MPa}$ & 1167395 & 25.4 & 1742.9 & 92.991 & & & & & & & & & & & & 368209 \\
\hline Cone resist. $-0.033 \mathrm{MPa}$ & 61396 & 47.5 & 216.29 & 21.326 & & & & & & & & & & & & 10343 \\
\hline Sat. hydraul. cond. & 62.98 & 670.8 & -0.221 & 0.683 & 17.351 & 184.8 & 0.981 & -0.519 & 0.134 & 1.04 & 11.1 & 0.85 & 0.167 & -0.085 & 0.016 & 0.751 \\
\hline
\end{tabular}

Table 7. Orthogonal contrasts from ANOVA, for the sandy loam soil. Only significant contrasts $(\mathrm{P} \leq 0.05)$ are reported. d.f. for contrasts $=1$; d.f. for error $=8$

Linear model: $\mathrm{Y}=\mathrm{A}+\mathrm{BX}$, quadratic: $\mathrm{Y}=\mathrm{A}+\mathrm{BX}+\mathrm{CX}^{2}$; cubic: $\mathrm{Y}=\mathrm{A}+\mathrm{BX}+\mathrm{CX}^{2}+\mathrm{DX}^{3}$, where $\mathrm{X}=\mathrm{URC} \%$

\begin{tabular}{|c|c|c|c|c|c|c|c|c|c|c|c|c|c|c|c|c|}
\hline \multirow[t]{2}{*}{ Variables } & \multicolumn{3}{|c|}{ Linear } & \multicolumn{5}{|c|}{ Quadratic } & \multicolumn{2}{|c|}{ Cubic } & \multicolumn{4}{|c|}{ error } & \multirow[b]{2}{*}{$\mathrm{D}$} & \multirow[b]{2}{*}{ S.S. } \\
\hline & S.S. & $\mathrm{F}$ & A & B & S.S. & $\mathrm{F}$ & A & B & $\mathrm{C}$ & S.S. & $\mathrm{F}$ & A & B & $\mathrm{C}$ & & \\
\hline Total sand & 7.695 & 11.6 & 57.175 & 0.239 & & & & & & & & & & & & 5.310 \\
\hline $2-1 \mathrm{~mm}$ sand & 6.232 & 437.6 & 0.438 & 0.215 & & & & & & & & & & & & 0.114 \\
\hline $1-0.5 \mathrm{~mm}$ sand & 14.069 & 13.6 & 2.581 & 0.323 & & & & & & & & & & & & 8.290 \\
\hline Total silt & 2.161 & 6.6 & 25.36 & -0.127 & & & & & & & & & & & & 2.613 \\
\hline $\mathrm{MWD}_{24 \text { months }}$ & 0.365 & 7.7 & 0.447 & 0.052 & & & & & & & & & & & & 0.3805 \\
\hline $\mathrm{MWD}_{36 \text { months }}^{24 \text { months }}$ & 0.313 & 6.9 & 0.652 & 0.048 & & & & & & & & & & & & 0.3615 \\
\hline $\mathrm{IIF}_{24 \text { months }}$ & 35.468 & 9.9 & 25.76 & -0.513 & & & & & & & & & & & & 28.672 \\
\hline $\mathrm{IIF}_{36 \text { months }}^{24 \text { months }}$ & 95.997 & 12.0 & 29.55 & -0.843 & & & & & & & & & & & & 63.924 \\
\hline Bulk density ${ }_{24 \text { months }}$ & 0.365 & 7.7 & 1.535 & -0.014 & & & & & & & & & & & & 0.3804 \\
\hline Bulk density ${ }_{36 \text { months }}$ & 0.313 & 6.9 & 1.487 & -0.009 & & & & & & & & & & & & 0.3615 \\
\hline Org. matter ${ }_{12 \text { months }}$ & 4.182 & 225.7 & 1.391 & 0.176 & 0.3888 & 21.0 & 1.571 & -0.004 & 0.02 & & & & & & & 0.1482 \\
\hline Org. matter 24 months & 3.735 & 949.6 & 1.392 & 0.166 & 0.118 & 30.0 & 1.492 & 0.067 & 0.011 & 0.073 & 18.5 & 1.457 & 0.249 & -0.047 & 0.004 & 0.0314 \\
\hline Org. matter ${ }_{36 \text { months }}$ & 1.383 & 21.6 & 1.615 & 0.101 & & & & & & & & & & & & 0.5118 \\
\hline $\mathrm{pH}_{12 \text { months }}$ & 0.133 & 14.1 & 8.026 & -0.031 & & & & & & & & & & & & 0.0759 \\
\hline $\mathrm{pH}_{24 \text { months }}$ & 0.133 & 14.9 & 8.031 & -0.031 & & & & & & & & & & & & 0.0714 \\
\hline Elect. cond. ${ }_{12 \text { months }}$ & 0.218 & 334.3 & 0.284 & 0.0402 & & & & & & & & & & & & 0.0052 \\
\hline Elect. cond. 24 months & 0.035 & 17.3 & 0.247 & 0.0162 & & & & & & & & & & & & 0.0164 \\
\hline Liquid limit & 43.398 & 11.6 & 34.064 & 0.567 & & & & & & & & & & & & 29.848 \\
\hline Plastic limit & 10.207 & 15.9 & 18.983 & 0.275 & & & & & & & & & & & & 5.1329 \\
\hline Cone resist. $-1.5 \mathrm{MPa}$ & & & & & 394980 & 6.3 & 3181.5 & -190.3 & 20.158 & & & & & & & 501390 \\
\hline $\mathrm{AWC}_{24 \text { months }}$ & 6.620 & 16.1 & 15.92 & -0.221 & & & & & & & & & & & & 3.281 \\
\hline Sat. hydraul. cond. & 62.976 & 36.1 & -0.198 & 0.679 & 16.834 & 9.9 & 0.978 & -0.475 & 0.121 & & & & & & & 13.954 \\
\hline
\end{tabular}

much to the form of the curve respect to the quadratic trend.

The interaction URC $\mathrm{x}$ months resulted significant only for the sandy loam soil. For this soil URC rates showed linear trends on times, which are not the same. At $9 \%$ URC rate it was observed a decline of organic matter with time that was not present in the range $3-6 \%$ of URC 
addition. Also this effect is probably due to the different microbiological activity during time in soil when different quantities of organic matter are present (Wander et al., 1994). Results clearly show that the best performance (minimum URC rate combined with maximum effect and duration) for organic matter was obtained at $6 \%$ rate of compost application in both soils.

\section{$3.5 \mathrm{pH}$ and electrical conductivity}

As reported in Table 1, pH of URC was 7.5. This material, when added to the two soils with higher $\mathrm{pH}$, produced a decrease of the $\mathrm{pH}$ values in accordance with the increasing rates of compost addition (Tables 3 and 4). This effect, was statistically significant after 12 and 24 months in the sandy loam soil at $9 \%$ rate of compost addition.

The $\mathrm{pH}$ of both soils showed significant linear decreasing trends at 12 and 24 months (Tables 6 and 7). In the silty clay soil also the quadratic trend resulted significant at 12 and 24 months. In this soil, over $6 \%$ rate of URC addition, the decreasing trend of $\mathrm{pH}$ became less pronounced than at $3 \%$ rate. The interaction of URC x months resulted significant. However, this effect can be neglected because is much smaller than the main effect (Snedecor and Cochran, 1967).

Electrical conductivity of the 1:5 soil-water extract significantly increased in both soils after 12 and 24 months, according to different rates of URC addition (Tables 3 and 4). This variable showed a significant increasing linear trend for both soils after 12 and 24 months.

However, according to Richards (1954), also the addition of URC at $9 \%$ rate did not produce any appreciable increment of salinity in either soil, in relationship to adverse effects on yields of many crops. The significant interaction in both soils between URC and months on electrical conductivity can be explained by considering that the draining effect of rainfall on salts, during the years, acts more intensely at high URC rates of application than at low ones. This may depend on the fact that, contrary to what happens when compost is applied at low rates, at high level of compost addition a higher quantity of ions not linked to the colloidal fraction of soil can be leached by rainfall.

\subsection{Atterberg limits}

Liquid limit increased in accordance with different rates of URC in both soils (Table 5). Its effect resulted significant at $9 \%$ rate for sandy loam soil, while in the silty clay soil it never became significant. Also the plastic limit increased and significance was achieved for the sandy loam soil at $6 \%$ and $9 \%$ rate of addition.

In the silty clay soil the trends never resulted significant (Table 6). On the contrary, in the sandy loam soil both Atterberg limits showed a significant linear positive trend (Table 7).

From these findings it is possible to argue that the beneficial effect of URC addition on Atterberg limits is more evident for the sandy loam soil, where organic matter plays a more important role as compared to silty clay soil, which is naturally rich in colloidal fractions.

\subsection{Penetrometric resistance}

Cone resistance, both in dry and wet conditions, increased in silty clay soil due to URC and this effect reached the statistical significance at addition rates $\geq 6 \%$ (Table 5). It can be argued that the increase in cone resistance of the silty clay soil was related to the increase of solid fraction (shell and glass fragments) provided by compost to soil that determines an increase of friction on the cone surface during penetration. This effect was also evidenced by the linear trend detected from the orthogonal contrast analysis (Table 6).

URC addition at 3\% rate to sandy loam soil significantly decreased the cone resistance in dry conditions while, in wet conditions, the decrease in cone resistance was not significant (Table 5). From the quadratic trend detected in this soil in dry condition (Table 7), it can be observed a decrease of cone resistance due to URC's addition up to $4.7 \%$ rate. Above this quantity, cone resistance increased. From these findings it can be argued that at low rate of compost addition the increase of cone resistance due to solid fragments supplied to soil by URC was less important than the positive counteracting effect of organic matter addition. Over $4.7 \%$, calculated through the quadratic model (Table 7), the effect of solids became prevalent and the cone resistance increased up to $9 \%$ of URC addition. The fact that the same trend was not detected in wet soil condition may have been determined by the increase of soil mois- 
Table 8. ANOVA of soil properties with significant interaction URC $\mathrm{x}$ months.

\begin{tabular}{|c|c|c|c|c|c|}
\hline & Source of Variation & d.f. & S.S. & $\mathrm{F}$ & $\mathrm{p}$ \\
\hline Bulk density & URC & 3 & 0.098 & 99.1 & $1.17 \times 10^{-13}$ \\
\hline \multirow[t]{3}{*}{ Silty clay soil } & months & 2 & 0.005 & 7.9 & 0.002 \\
\hline & URC $\times$ months & 6 & 0.014 & 6.8 & $2.53 \times 10^{-4}$ \\
\hline & Error & 24 & 0.008 & & \\
\hline $\mathrm{pH}$ & URC & 3 & 0.214 & 18.8 & $1.72 \times 10^{-6}$ \\
\hline \multirow[t]{3}{*}{ Silty clay soil } & months & 2 & 0.234 & 30.8 & $2.34 \times 10^{-7}$ \\
\hline & URC $\times$ months & 6 & 0.095 & 4.2 & 0.0052 \\
\hline & Error & 24 & 0.091 & & \\
\hline Electrical conductivity & URC & 3 & 0.353 & 96.7 & $1.54 \times 10^{-13}$ \\
\hline \multirow[t]{3}{*}{ Silty clay soil } & months & 2 & 0.345 & 141.8 & $5.08 \times 10^{-14}$ \\
\hline & URC $\times$ months & 6 & 0.173 & 23.7 & $5.61 \times 10^{-9}$ \\
\hline & Error & 24 & 0.029 & & \\
\hline Organic matter & URC & 3 & 9.128 & 105.6 & $5.79 \times 10^{-14}$ \\
\hline \multirow[t]{3}{*}{ Sandy loam soil } & months & 2 & 0.077 & 1.3 & 0.278 \\
\hline & URC $\times$ months & 6 & 0.872 & 5.0 & 0.002 \\
\hline & Error & 24 & 0.691 & & \\
\hline Electrical conductivity & URC & 3 & 0.145 & 40.0 & $1.72 \times 10^{-9}$ \\
\hline \multirow[t]{3}{*}{ Sandy loam soil } & months & 2 & 0.250 & 103.0 & $1.66 \times 10^{-12}$ \\
\hline & URC $\times$ months & 6 & 0.128 & 17.6 & $1.03 \times 10^{-7}$ \\
\hline & Error & 24 & 0.029 & & \\
\hline AWC & URC & 3 & 4.768 & 3.8 & 0.024 \\
\hline \multirow[t]{3}{*}{ Sandy loam soil } & months & 2 & 95.28 & 113.1 & $6.10 \times 10^{-13}$ \\
\hline & $\mathrm{URC} \times$ months & 6 & 6.46 & 2.6 & 0.047 \\
\hline & Error & 24 & 10.11 & & \\
\hline
\end{tabular}

ture content and especially of organic matter supplied by compost, with consequent decrease of cone resistance.

\subsection{Available Water Capacity (AWC)}

In silty clay soil, $3 \%$ of URC addition increased AWC (Table 3). This effect was statistically significant $(\mathrm{P} \leq 0.05)$ and still present 24 months after compost application. The URC rates $>3 \%$ significantly increased AWC after 24 months.

In sandy loam soil, there was no significant change in AWC before 24 months after URC application. At 24 month URC addition determined a decrease of AWC with respect to not treated soil. The linear trend, detected by orthogonal contrast analysis (Table 7) was not present after 36 months from URC addition (Table 4).

The interaction URC $\mathrm{x}$ months was significant for the sandy loam soil (Table 8), probably due to the same reasons that justify the interaction observed in the organic matter content. The opposite effect observed for the two soil types may be due to the increase of the sand fraction, according to the increasing rates of compost application (Table 2). In fact, the increase in sand fraction provided by URC might have had a negative effect on the water reten- tion capacity of the soils. On sandy loam soil, which is naturally richer in sand fraction, this negative effect on AWC of the organic matter supplied with compost may have been more effective than the positive one. On the contrary, in the silty clay soil, the naturally higher clay content may have counteracted the negative effect of the increase in sand fraction.

\subsection{Saturated hydraulic conductivity}

The minimum rate $(3 \%)$ of URC produced a significant positive increase in saturated hydraulic conductivity of silty clay soil (Table 5) by about 1.6 times. In the sandy loam soil $9 \%$ compost addition increased hydraulic conductivity by about 8.5 times. In the silty clay soil the same rate increased hydraulic conductivity by about 2.4 times.

The orthogonal contrast analysis demonstrated a quadratic trend of this parameter in both soils. In the silty clay soil also the cubic trend was demonstrated, but it did not add much to the shape of the curve.

The increase of saturated hydraulic conductivity under effect of increasing URC addition can be explained by the corresponding increase in aggregate stability and consequent ameliora- 
tion of water infiltration (Dexter, 1988), as demonstrated in Table 3 by the increase in the MWD values observed 12 months after compost addition.

\section{Conclusions}

It appears quite evident that the majority of the soil properties investigated were significantly affected by $3 \%$ of URC 12 months after addition. At this rate of application, the effect on silty clay soil was significantly positive on Iif index and hydraulic conductivity. On the contrary, significant negative effects were observed on electrical conductivity at $3 \%$ rate and on bulk density at $9 \%$. The effect of URC on MWD and AWC became significant and positive after 24 months, at $6 \%$ rate. At this time, organic matter resulted significantly increased by URC at $3 \%$ rate. In silty clay soil, $6 \%$ rate of URC was sufficient to determine a significant negative effect on cone resistance in dry and wet conditions. The effects on Iif, bulk density and organic matter were still present after 36 months from URC application.

In the sandy loam soil, after 12 months from $3 \%$ rate of URC addition, a positive significant effect was observed on organic matter, and cone resistance in dry soil condition. On the contrary, electrical conductivity was negatively affected by $3 \%$ URC addition. At 12 months, the minimum quantity to observe a positive significant difference on bulk density, hydraulic conductivity and plastic limit was $6 \%$ and $9 \%$ for the liquid limit.

In the same soil, AWC and MWD resulted significantly ameliorated after 24 months at 3\% and $9 \%$ of URC addition, respectively. On the contrary $9 \%$ rate determined a significant negative effect on Iif.

In the sandy loam soil, the effects on MWD, Iif, bulk density and organic matter lasted up to 36 months.

Under these experimental conditions, 3\% rate of URC incorporation to soils appears to be the minimum quantity able to improve most of the soil properties influencing fertility. What the results show is that, to achieve sustainability of urban refuse compost application to agricultural soil, further research is needed to investigate soil property changes in the range be- tween $0 \%$ and $3 \%$. It can also be argued that repeated application of URC with a high content of inert sandy residues may affect soil textural properties.

This effect can be considered either positive or negative depending on the original physical, chemical and biological characteristics of soil. Therefore, the possible consequences on texture change due to URC application should be included among the criteria that should be taken into consideration when dealing with directives on biomass application to soil.

\section{Acknowledgements}

Dr. Paolo Bazzoffi: Experimental layout, statistics, laboratory and field analyses.

Dr. Sergio Pellegrini: Laboratory and field analyses statistics.

Andrea Rocchini: Laboratory and field analyses.

\section{References}

Armstrong A.C., Burt T.P. 1993. Nitrate losses from agricultural land. In: Burt T.P. (ed.): Nitrate processes, patterns and management, 239-267. J. Wiley and Sons Ltd., New York.

ASAE (American Society of Agricultural Engineers) 1982. Soil penetrometer. Agr. Eng. Yearbook, ASAE Standard, ASAE S313.1, ASAE, St. Joseph, MI.

Ballif J.L., Herre C. 1988. Contribution a l'étude du ruissellement de sols viticoles en Champagne (Contribution to the study of surface runoff in Champagne viticultural soils). Effets d'une couverture du compost urbain. C.R. Acad. Agr. Fr., 74:105-110.

Bazzoffi P., Pellegrini S., Rocchini A., Morandi M., Grasselli O. 1998. The effect of urban refuse compost and different tractors tyres on soil physical properties, soil erosion and maize yield. Soil Tillage Res., 48:275-286.

Blake G.R., Hartge K.H. 1986. Bulk density. In: Klute A. (ed.): Methods of Soil Analysis, Part 1, Second Edition, 363-382. American Society of Agronomy, Madison, WI.

Bowles J.E. 1986. Engineering Properties of Soils and Their Measurement. Third Edition. McGraw-Hill Publishing Co, New York.

Bradford J.M. 1986. Penetrability. In: Klute A. (ed.): Methods of Soil Analysis, Part 1, Second Edition, 463478. American Society of Agronomy, Madison, WI.

Chisci G., Bazzoffi P., Mbagwu J.S.C. 1989. Comparison of aggregate stability indices for soil classification and assessment of soil management practices. Soil Technol., 2:113-133.

Council of Europe 1995. European Soil Resource. Nature and Environment, Publ. n. 71. 
de Haan F.A.M. 1989. General aspects of compost uses in agriculture with respect to soil quality. In: Proc. Int. Symp. "Compost production and use", 167-177. S. Michele all'Adige, Italy.

Degens B.P., Sparling G.P., Abbott L.K. 1994. The contribution from hyphae, roots and organic carbon constituents to the aggregation of a sandy loam under long-term clover-based and grass pastures. Eur. J. Soil Sci., 45:459-468.

Dexter A.R. 1987. Mechanics of root growth. Plant Soil, 97:401-406.

Dexter A.R.1988. Advances in characterization of soil structure. Soil Tillage Res., 11:199-238.

Edwards A.P., Bremner J.M. 1967. Microaggregates in soil. J. Soil Sci., 18:64-73.

Felton G.K. 1995. Temporal variation of soil hydraulic properties on urban amended mine soils. Trans. ASAE, 38:775-782.

Gee G.W., Bauder J.W.1986. Particle-size analysis. In: Klute A. (ed.): Methods of Soil Analysis, Part 1, Second Edition, 383-411. American Society of Agronomy, Madison, WI.

Giusquiani P.L., Pagliai M., Gigliotti G., Businelli D., Benedetti A. 1995. Urban waste compost: effects on physical, chemical, and biochemical soil properties. J. Environ. Qual., 24:175-182.

Hayes M.H.B. 1991. Concepts of the origins, composition, and structures of humic substances. In: Wilson W.S. (ed.): Advances in soil organic matter research: the impact on agriculture and the environment, 3-22. The Royal Society of Chemistry, Special Publication n. 90, Cambridge, UK.

He X.T., Logan T.J., Traina S.J. 1995. Physical and chemical characteristics of selected U.S. municipal soil waste composts. J. Environ. Qual., 24:543-552.

Hillel D. 1980. Fundamentals of Soil Physics. Academic Press, San Diego, California.

Horn R., Taubner H., Wuttke M., Baumgartl T. 1994. Soil physical properties related to soil structure. Soil Tillage Res., 30:187-216.

Hu S.W., Shy C.M. 2001. Health effects of waste incineration: A review of epidemiologic studies. J. Air Waste Manag. Assoc., 51:1100-1109.

Jackson R.M. 1975. Soil fungi. In: Walker N. (ed.): Soil microbiology. London, Butterworths.

Jannone R., Ferrari G., Rodolfi G. 1984. Applicazione del metodo pedogeomorfico NULM alla cartografia di dettaglio dei suoli nel centro sperimentale di Fagna (Application of NULM pedogeomorphyc method to detail cartography of soils located in the experimental centre of Fagna). Annali Istituto Sperimentale per lo Studio e la Difesa del Suolo di Firenze, XV: 53-80.

Kemper W.D., Chepil W.S. 1965. Size distribution of aggregates. In: Black C.A. (ed.): Methods of soil analysis, Part 1:499-510. American Society of Agronomy, Madison, WI.
Khaleel R., Reddy K.R., Overcash M.R. 1981. Changes in soil physical properties due to organic waste application: a review. J. Environ Qual., 10:133-141.

Kladivko E.J., Nelson D.W. 1979. Surface runoff from sludge-amended soils. J. Water Pollut. Control Fed., 51:100-110.

Klute A. 1986. Water retention: laboratory methods. In: Klute A. (ed.): Methods of Soil Analysis, Part 1, Second Edition:635-662. American Society of Agronomy, Madison, WI.

Klute A., Dirksen C. 1986. Hydraulic conductivity and diffusivity: laboratory methods. In: Klute A. (ed.): Methods of Soil Analysis, Part 1, Second Edition:687734. American Society of Agronomy, Madison, WI.

Köppen W. 1936. Das geographische System der Klimate. Reported by Pinna M. in: Climatologia, 302347. UTET, Torino, 1977.

Krishna Murthi G.S.R., Huang P.M. 1987. Influence of constituents on the stability of mechanical separates of soils representing major taxonomic orders. Appl. Clay Sci., 2:299-308.

Marshall K.C. 1976. Interfaces in microbial ecology. Harvard University Press, Cambridge, MA.

Materechera S.A., Kirby J.M., Alston A.M., Dexter A.R. 1994. Modification of soil aggregation by watering regime and roots growing through beds of large aggregates. Plant Soil, 160:57-66.

Monreal C.M., Schnitzer M., Schulten H.R., Campbell C.A., Anderson D.W. 1995. Soil organic structures in macro and microaggregates of a cultivated brown chernozem. Soil Biol. Biochem., 27:845-853.

Nemec A.F.L. 1991. Power Analysis Handbook for the Design and Analysis of Forestry Trials. In: Bergerud W. (ed.): Biometrics Information Handbook No. 2. Forest Science Research Branch, B.C. Ministry of Forests, Victoria, Canada.

Organization for Economic Cooperation and Development 1999. Environmental Data. Compendium 1999. OECD, Paris.

Pagliai M., Guidi G., La Marca M., Giachetti M., Lucamante G. 1981. Effect of sewage sludges and compost on soil porosity and aggregations. J. Environ. Qual., 10:556-561.

Poulsen O.M., Breum N.O., Ebbehoj N., Hansen A.M., Ivens U.I., Vanlelieveld D., Malmros P., Matthiansen L., Nielsen B.H., Nielsen E.M., Schibye B., Skov T., Stenbaek E.I., Wilkins K.C. 1995. Sorting and recycling of domestic waste. Review of occupational health problems and their possible causes. Sci. Total Environ., 168:33-56.

Raper R.L., Reeves D.W., Burt E.C., Torbert H.A. 1994. Conservation tillage and traffic effects on soil condition. Trans. ASAE, 37:763-768.

Rhoades J.D. 1996. Salinity: electrical conductivity and total dissolved solids. In: Sparks D.L., Page A.L., Helmke P.A., Loeppert P.N., Soltanpour P.N., Tabatabai M.A., Johnson C.T., Sumner M.E. (eds.): 
Methods of Soil Analysis, Part 3, 417-435. American Society of Agronomy, Madison, WI.

Richards L.A. 1954. Diagnosis and Improvement of Saline and Alkaline Soils. USDA Handbook No. 60, Washington, D.C.

Snedecor G.W., Cochran W.G. 1967. Statistichal methods. Iowa State Univ. Press, 6th edition, Ames, Iowa.

Taylor H.M. 1971. Effects of soil strength on seedling emergence, root growth and crop yield. In: Carleton W.M., Barnes K.K., Taylor H.M., Throckmorton R.I., Van den Berg G.E. (eds.): Compaction of Agricultural Soils: 292-312. ASAE Monograph, St. Joseph, MI.

Tisdall J.M., Oades J.M. 1982. Organic matter and water-stable aggregates in soils. J. Soil. Sci., 33:141-163.

Turner M.S., Clark G.A., Stanley C.D., Smajstrla A.G. 1994. Physical characteristics of a sandy soil amended with municipal solid waste compost. Soil Crop Sci. Soc. Florida Proc., 53:24-26.

USDA (United States Department of Agriculture) 1975. Soil Taxonomy, a Basic System of Classification for Making and Interpreting Soil Surveys. USDA, Agriculture Handbook 436, Washington, D.C.

Van Bavel C.H.M. 1949. Mean weight diameter of soil aggregates as a statistical index of aggregation. Soil
Sci. Soc. Am. Proc., 14:20-23.

Vigna Guidi G., Pini R., Petruzzelli G. 1989. Effects of compost on chemical and physical characteristics of soil. In: Proc. Int. Symp. "Compost production and use”, 201-216. S. Michele all'Adige, Italy.

Walkley A., Black A. 1934. An examination of the Degtjareff method for determining soil organic matter and proposed modification of the chromic acid titration method. Soil Sci., 37:29-38.

Wander M.M., Traina S.J., Stinner B.R., Peters S.E. 1994. Organic and conventional management effects on biologically active soil organic matter pools. Soil Sci. Soc. Am. J., 58:1130-1139.

Whalley W.R., Dumitru E., Dexter A.R. 1995. Biological effects of soil compaction. Soil Tillage Res., 35:5368.

World Wildlife Fund and The Conservation Foundation 1991. Getting at the SoMSWCe: Strategies for Reducing Municipal Solid Waste. World Wildlife Fund, Washington, D.C.

Yasuda Y. 1996. Towards an Optimal Waste Management and Recycling System With Special Reference to Japanese Cities. In: Fernandez A.L. (ed.): Recycling in Asia: Partnerships for Responsive Solid Waste Management. 109-124. UNCRD Research Report Series, no. 21. 